\title{
Study on the Actual Effect of Ideological and Political Education of College Students in Micro - media Environment
}

\author{
Jing Yang \\ School of Politics, Xi'an University, 710065
}

\begin{abstract}
Keywords: Micro-Media Environment; College Students; Ideological and Political Education; Actual Effect; Study
\end{abstract}

\begin{abstract}
The mission of media is to spread. Under the condition of communication, use media-guided role to promote publicity and dissemination through interactive media operations. In recent years, with the rapid development of information technology, microblog, WeChat, micro-film, micro-shop and other "micro" known for the media in the ascendant, which not only change people's ideas and lifestyles, but also put forward higher requirements for college students ideological and political education on the new situation. How to correctly face and rationally use micro-media to let micro-media serve better for college students ideological and political education has been a problem that needs ideological and political education workers to consider seriously.
\end{abstract}

\section{Introduction}

In the ideological and political construction process for college students through micro-media, use interactive means of communication to promote the political form. The use of data information link will bring college students ideological and political education work more opportunities and challenges. Adopt strictly the key situation of social education and combine focus of education and multi-level education system construction to promote and improve the ideological and political education system of college students. Besides, it can also make full use of micro-media fragmented information mode, use interactive communication effect and analyze the effect of ideological and political education to promote ideological and political education effectiveness from a wide range.

\section{Features of Information Dissemination in the Environment of Micro - media}

The Main Body and Channel of Information Dissemination Are Ubiquitous. With the popularity of mobile terminals and the opening of communication $4 \mathrm{G}$ era, the information channel is more fast and convenient. In this development process, people can effectively mobilize and access information through real-time access. Therefore, the more positive way to deal with contemporary college students ideological and political education is proceeded based on the main body of information dissemination and channel. The environment of micro-media era can make the ideological and political communication of college students more tendencies. The main body of information dissemination in micro-media era is no longer television and other three traditional media, but use different network development and promotion modes, such as microblog, WeChat and so on, and even can use self-media.

The Content of Information Dissemination Is Diversification. The content of information dissemination has been the structure of a wide range of public opinion system in the micro-media era. It is said that the information for the era of micro-media needs to have a sound sense of screening. For the acquisition of massive information, it is necessary to go through a large number of information and need to eliminate false and pornographic information in the inevitably process of public opinion. Due to the development of micro-media situation, the channel that people access to information has shown a explosive development trend. Therefore, in the development of media sub-center, people for the acceptance of information presents active request and passive acceptance. In the process of acceptance, people's understanding of micro-media era has become a conscious behavior under diversified development mode. The diversified development leads to the prevalence of information and communication channels. The progress of ideological and political development 
and education of college students should be synchronized with the development of micro-media.

\section{The Challenge of Micro - media Public Opinion Environment to the Ideological and Political Education of College Students}

The Rapid Development of Micro-media Technology Makes the Information Fragmented. The protection role of micro-media public opinion is mainly reflected through microblog, WeChat and other advanced development of new media technology. With the rapid development of social platform, information dissemination mode of media era has been inevitable in the earth-shaking changes. When people access information rapidly, they also communicate and exchange the correctness and stability of information. A large number of individuals' information update can achieve fragmented update of information education and identity, which provide possibility for the quick access to educational information and real-time update. The biggest feature of fragmented information is that people can quickly grasp the amount of short and pithy information and reduce the information recording and memory time, which is suitable for modern learning style and people will not have too much reading and learning fatigue.

The Identity of the Mainstream Ideology Is Gradually Weakened. Communication is more convenient and people's values develop more vigorous due to microblog and WeChat in micro-media. Based on the recognition mechanism and the change of family emotion, the communication of consciousness has evolved into a diversified and complicated development process. Because of the openness and interactive development of information dissemination, the choice of lifestyle and self-realization can be presented for the diversity of values. Therefore, there may be more possibilities for people to understand and accept the same thing and there are obvious differences. As the traditional mainstream media has gradually weakened and modern new micro-media has become an important way of mass education, the public can publish their own identity information using more microblog and WeChat social media. At the same time, this also brings challenges to the dominant position of the mainstream media. For example, it may be someone else who will unconsciously carry out other information in some speculations. If people have ulterior motives at this time, it may appear some vicious incidents that some people attack the government and the mainstream awareness.

It Changed the Impact of Public Opinion on the Public Environment. The communication platform of micro-media era is microblog and WeChat. When micro-media social platform and public opinion transmission have a profound change, the new spread way can bring an updated communication environment for pushing information. There is no possibility to monopolize media platform in modern society, but people can take the initiative to question, and then issue and update information. This kind of communication environment is an environment that can develop a interaction communication of information in the new era. It is also an environment that can change from one-way information transmission to multi-directional transmission. People publish information through the mobile terminal anytime and anywhere, which can release the core of the rights.

The Influence of Ideological Struggle on College Students' Ideological and Political Education. As the field of ideology for the renewal of information is more liberal, in the hostile forces and our struggle environment and space, people can express freely and use the content of information dissemination to make the audience has a flexible environment. Freedom of expression allows people to freely express their views on hostile forces and our side, but this will inevitably lead to more contradictions between hostile forces and our side. If not more focus on ideological and political education for red education content, it may make students misunderstand the ideological and political education. In other words, only in the public opinion to play a positive way to guide, can educators overcome problems of ideological and political education of college students. If not guide the major mode of education and important educational effectiveness correctly, educators can not subtly implement ideological and political education. Besides, it also bring the enemy's wrong idea of ideological field, which is not conducive to the ideological and political education. 


\section{The Content of Ideological and Political Education of College Students under the Innovation of Micro - media Public Opinion Environment}

Under the micro-media environment, people's ideological and political education for the innovation of public opinion environment needs to carry out innovative development. In the process of reforming ideological and political education, it is necessary to combine the operation of the micro-media public opinion environment and the way of network transmission. In order to regulate the construction of the network platform of our mainstream ideology and political theory courses, we need to make more publicity for our mainstream political ideology in the process of acquiring knowledge and information. The contents of this propaganda should be more elegant and popular and it is a development process of ideological diversification.

Innovate the Content of Ideological and Political Education for College Students. The ideological and political education of college students in the era of micro-media can not always use the traditional communication content to work. Only redefine the content of ideological and political education, can make students have a better interest in ideological and political work. In the development process of rich network public opinion and rapid popularization of ideological and political work in the network, educators should actively call for and encourage organizations at all levels to update political work content updates in the new era. In the maintenance of ideological and political platform and content selection, educators must learn the revolutionary predecessors advanced deeds and combine with the advanced character deeds in the new era. Therefore, in the process of teachers conducting the ideological and political education, school should arrange teachers to use advanced government microblog to strengthen the effectiveness and intensity of information disclosure and the dignity of the official authority information can not be ignored. In the popularization of advanced political deeds, educators should combine the good things and advanced models around college students and put an end to the impractical phenomenon of ideological and political work.

In the development of popular network period, the ideological awareness of college students can be improved through the political and ideological education, which can help students get new knowledge. It needs to combine with examples of daily learning to let students realize the enthusiasm of learning. Only develop modern education and innovative educational content of ideological and political development with the times, can make students' ideological and political education primary and secondary channels more smooth. Educators should make full use of online education technology and content to let college students be immersed in the content of teaching, so as to form a correct world view.

The Method of Ideological and Political Education for College Students in Micro - media Environment. The method of ideological and political education for college students in the era of micro-media can be varied. Rich ideological and political work education is the result that closely links to the actual development of education results in the new era of network. A lot of colleges and universities have put school's educational platform construction on the agenda. As the development of microblog and WeChat, college students accept them very quickly for the rapid development of terminal and per capita penetration rate has reached more than $98 \%$. Smooth channels of appeal can accelerate the exchange and communication speed of teachers and students. In order to improve college students' depth of thought, teachers should guide them and take college students as the main body of ideological and political work and then achieve the ultimate goal of education. In particular, the network connectivity in many colleges and universities has a wide range and network connection speed is very fast. Therefore, in the process of building campus intelligent network, the more use of a variety of rational expression model, the more you can attract fans. Educators can achieve the purpose of benign education by using micro-video when serve the ideological and political work.

Cultivating qualified personnel of socialist modernization can promote construction and development of ideological and political quality of the strategic task, which is useful to fully understand the popularity of the network. Young college students of the new era can learn in the spare time and form their life and world outlook by using micro-platform approach when study 
political work. In the process of studying the ideological and political education of college students, it is found that the law of self - learning is a way to enhance their consciousness under the classroom learning mode.

The Construction of Innovative Ideological and Political Education Platform for College Students in Micro - media. To build ideological and political work of the educational platform is the inevitable requirement of ideological and political education of modern college students in the internet age and micro-media environment. The means of information communication in network social can liberate human nature fully. Under the premise of freedom and equality, through the benign ideological education and the construction of harmonious teacher-student relationship, college students can learn freely. The behavior and thinking patterns of the production and dissemination of information should also be appropriate changed. For example, a very popular method in micro-media environment is to tell story of interesting ideological and political work by using WeChat, which can let students learn interesting knowledge and imperceptibly enhance their political quality. Students in the internet era need to face the intricate human development during the formation process of their life outlook, values and world outlook. Therefore, in the construction process of ideological and political network platform, school's education and social environment factors should also be considered. For example, if the modern political events or social events can be as an opportunity for ideological and political education of college students or become the material of education, it will play a better role to enhance the development of thinking and political literacy of college students.

It is necessary that the source of information participate in and then it may produce valuable micro-media network. A source of information refers to any publication that generates information. Write an article is the source of information and make a valuable change to the information or publish a comment is also the source of information. As long as there is a new information that is added information, and there may be audience interested in, which does not require publishers to have a press card and use the official style and writing. Micro-media transmission refers to the spontaneous spread rather than through the newsstand, such a distribution channel. So two conditions are needed: the information source is open and there is no copyright barrier on the delivery path. Interested individuals spontaneously spread it and the micro-media channel is completely free.

\section{Conclusion}

Micro-media is a scientific and effective platform for the ideological and political education of college students. It can actively promote the timeliness of ideological and political education of college students. The micro-media environment provides a variety of educational means for the ideological and political education of college students. In the use of micro-media, teachers should combine with the school education resources and make the two effective integration, so that the role of micro-media can be given a full play. The full development of communication and information technology and the promotion of virtual teaching environment is the future direction of ideological and political education of college students. How to combine teaching with various new media and communication carrier scientific and efficient to continuously improve the quality of education and teaching is a realistic problem that needs to be studied and solved by educators.

\section{Reference}

[1] X.H. Li. Study on the Actual Effect of Ideological and Political Education of College Students in New Media [D]. Dalian University of Technology, 2016.

[2] Z.H. Huang. The Impact of Micro-media on the Ideological and Political Education of College Students and Countermeasures [D]. Guangdong University of Finance and Economics, 2016.

[3] Y.S. Xiang. Study on the Actual Effect of Ideological and Political Education of College Students Based on Mobile Internet [D]. Southwest University, 2015.

[4] H. Liu. Study on the Actual Effect of Ideological and Political Education of College Students 
under the Background of Network [D]. Xihua University, 2015.

[5] J. Tang. Study on the Actual Effect of Ideological and Political Education of Ethnic Minority College Students in the New Media Environment [J]. Heilong jiang Nationalities Series, 2014, (05): 171-174.

[6] A. Xiang. Study on the Actual Effect of College Students' Ideological and Political Education [D]. Guangxi Normal University, 2014.

[7] X.Y. Liu. Study on the Actual Effect of Ideological and Political Education of College Students in New Media [D]. Liaocheng University, 2014.

[8] A.P. Qin. Study on the Actual Effect of Ideological and Political Education of Higher Vocational College Students [D]. Yangtze University, 2014.

[9] S.Z. Zhang. Analysis of the Actual Effect of Ideological and Political Education of College Students from the Perspective of Theory [D]. China Ocean University, 2012.

[10] T. Zhang. Study on the Actual Effect of Ideological and Political Education of "90 generation" College Students [D]. Zhejiang University of Technology, 2012.

[11] X.Z. Hu. Study on the Actual Effect of Ideological and Political Education of College Students Based on Modern Educational Technology [D]. Anhui University of Engineering, 2010.

[12] Y. Hu. Study on the Actual Effect of Ideological and Political Education of College Students from the Perspective of Attitude Theory [D]. Liaoning Normal University, 2010. 